1999

\title{
On the Market for Corporate Control
}

Clifford W. Smith Jr.

Follow this and additional works at: https://scholarlycommons.law.case.edu/caselrev

Part of the Law Commons

\section{Recommended Citation}

Clifford W. Smith Jr., On the Market for Corporate Control, 50 Case W. Rsrv. L. Rev. 259 (1999)

Available at: https://scholarlycommons.law.case.edu/caselrev/vol50/iss2/8

This Symposium is brought to you for free and open access by the Student Journals at Case Western Reserve University School of Law Scholarly Commons. It has been accepted for inclusion in Case Western Reserve Law Review by an authorized administrator of Case Western Reserve University School of Law Scholarly Commons. 


\title{
ON THE MARKET FOR CORPORATE CONTROL
}

\author{
Clifford W. Smith, Jr. ${ }^{\dagger}$
}

Over the past two decades, I have interacted with Henry Manne, his organizations, and his ideas in a number of capacities. I taught courses in finance and insurance in the Program for Federal Judges offered by his Law \& Economics Center. I attended the Law for Economists program also offered by the Law \& Economics Center. I taught a course on the economics of organizations to law students as a visiting professor at the George Mason Law School. And I studied Henry's writings, especially those on the market for corporate control. This interaction has been professionally stimulating and personally fulfilling, especially the opportunity to teach the federal judges. It was a forum quite unlike the courtroom: I was not selected and paid to offer an expert opinion that might further a particular party's interest; there were no jurors watching; there were ample opportunities to explore issues both formally in class and informally afterwards. I quickly developed a deep respect for the dedication and intellect of our federal judiciary. Teaching in these programs also provided the opportunity for interaction with other instructors-academics like Armen Alchain, Orley Ashenfelder, George Benston, Pat Danzon, Mike Jensen, Bill Meckling, George Priest, Dick Roll, and Paul Samuelson. I will forever be grateful to Dean Manne for providing me with these opportunities.

My central purpose here is to discuss Manne's scholarship. Legal scholars widely acknowledge the pivotal role he played in the development of the area of Law and Economics as a respected discipline within legal scholarship and education. Professor Carney has done a masterful job in reviewing these contributions. ${ }^{1}$ I want to expand on one point raised by Carney and then focus on the impact that this legal scholarship has had on economics and finance.

Carney notes that Manne introduced economic reasoning to provide a positive analysis of corporate law. I believe this is a noteworthy contribution. In the 1960 s, legal studies were primarily normative. Yet normative analysis ultimately demands a rich set of positive

$†$ Louise and Henry Epstein Professor of Business Administration, William E. Simon Graduate School of Business, University of Rochester.

I See William J. Carney, The Legacy of "The Market for Corporate Control" and the Origins of the Theory of the Firm, 50 CASE W. RES. L. REV. 215 (1999). 
theories. A positive theory provides an understanding of the consequences of potential choices. Useful evaluations of legal rules are virtually impossible without the explicit, or implicit, use of positive theories. ${ }^{2}$ For example, one cannot decide which legal rule might be better without first understanding the consequences of the alternative rules, and this is precisely what a positive theory does. Thus, normative legal analysis really does not face a choice between a positive theory or no theory, but between a carefully articulated, internally consistent, ideally empirically verified theory, or a shoot-from-thehip, go-with-your-intuition "theory."

When I began my $\mathrm{Ph} . \mathrm{D}$. studies almost three decades ago, in my first microeconomics theory class we worked our way through Paul Samuelson's Foundations ${ }^{3}$ on an equation-by-equation basis. Conventional microeconomic theory treated the firm as a black box that transformed inputs (labor, capital, and raw materials) into output; the amount of output produced from a given level of input was determined by "technology." Much of this analysis of the theory of the firm focused on first- and second-order conditions for profit maximization.

Traditionally in this analysis, little attention is paid to the internal organization of the firm: whether decisions are centralized or decentralized; how specific tasks are bundled into specific jobs within the organization; whether a given activity is performed within a department, a subsidiary, or is out-sourced; how transfer prices between business units are set; how performance-evaluation systems are structured; and how employees are compensated. In business schools, where such questions are difficult to avoid, the analysis of organizational structure has generally been addressed in courses that have their intellectual roots in psychology, not economics.

For economists to address these questions about the internal structure of the firm, we have to open that black box and examine the organizational architecture. By organizational architecture, I explicitly refer to three critical features of the firm: (1) the assignment of decision rights within the firm; (2) the performance evaluation system; and (3) the corporate reward system. ${ }^{4}$ Recognizing alternative architectures, analyzing the incentives created by the alternatives, and explaining the distribution of choices across firms have materially enriched our understanding of these organizational decisions.

As far back as Hayek, economists have recognized that the structure of an organization affects the information used in decision

2 See Michael C. Jensen, Organization Theory and Methodology, 58 ACCT. REV. 319, 319 (1983) (arguing that positive theories are necessary for "purposeful decision making").

3 Paul Anthony Samuelson, Foundations OF ECONOMIC ANALYSIS (1947).

4 See JAMES A. BRICKLEY ET AL., ORganizational ARCHITECTURE: A MANAGERIAL ECONOMICS APPROACH 4 (1996). 
making. ${ }^{5}$ For firms, a material challenge in discovering customer demands while reducing costs is that important information for decision-making is generally held by many different individuals. Furthermore, this information is often expensive to transfer. In such cases, a decision-making process that requires that this information be communicated to headquarters for approval is likely to be cumbersome, resulting in lost opportunities.

A second complication is that decision-makers do not necessarily have appropriate incentives to make value-increasing decisions, even if they have the relevant information; there are agency problems. Thus, the principle challenge in structuring firms is maximizing the likelihood that decision-makers have both the relevant information to make good decisions and the incentives to use the information productively. Within firms there are no automatic systems either for assigning decision rights or for motivating individuals to use information to promote the firm's objectives. These systems are created as the architecture of the organization is established. For instance, through the assignment of decision rights, employees are granted authority over how to use company resources. But employees have fewer incentives to use company resources efficiently than owners. To help control such agency problems, the firm must develop control systems-both a performance-evaluation system and a reward system-to align the interests of the decision-makers with those of the owners.

Except for very small firms, the CEO is unlikely to have the relevant information for most major decisions. Consequently, the firm faces three basic choices in designing the organization. First, decision rights can be decentralized to individuals with better information. This choice assigns decision-making authority to employees with the relevant specific information. But this decentralization process, which moves the decision rights to where the information is produced, gives rise to agency problems within the firm. Again, control systems must be developed and implemented to manage these problems.

Second, the CEO can attempt to acquire the relevant information to make better decisions. However, obtaining and processing the relevant information can be quite time consuming and costly. Moreover, in this process of centralization, which moves the information to where the decision rights reside, texture in the information is generally lost.

5 See F.A. Hayek, The Use of Knowledge in Society, 35 AM. ECON. REV. 519, 519-20 (1945) ("The economic problem of society is . . . a problem of the utilization of knowledge not given to anyone in its totality."). 
Finally, the CEO still might make most major decisions even without the relevant information. The benefits of this choice are fewer agency problems among managers within the firm and hence little need for a detailed internal control system. The costs of such centralization, however, will come in the form of sub-optimal decisions resulting from the lack of specific information.

In each of these cases, unless the CEO also owns the firm, there are still agency problems between the owners and the CEO. Henry's papers have played a particularly important role in highlighting important mechanisms for controlling this owner-manager agency conflict. His ideas on shareholders as specialized risk bearers in addition to suppliers of capital, shareholder voting, the market for management, and the market for corporate control have lead to a richer understanding of these mechanisms in controlling this basic corporate incentive problem.

Tremendous progress has been made over the past few decades in developing a richer understanding of these organizational details; progress that has occurred from the complementary efforts of legal, financial, and economic scholars. I believe that it is noteworthy that so much of this analysis was produced by scholars in law schools and business schools rather than economics departments. ${ }^{6}$ Scholars in professional schools appropriately operate at a lower level of abstraction than our colleagues in arts and sciences departments. For example, we see the same thing if we contrast research in an engineering school with that in a physics department. Our students' chosen careers require them to deal with this institutional detail. This, in turn, creates a derived demand for such analysis by both law and business school scholars.

6 The most notable exception to this proposition appears to be the Economics Department at UCLA with Armen Alchian, Harold Demsetz, and Jack Hirshleifer. Yet, their attention to these institutional issues was apparently spurred in important ways by their association with the RAND Corporation. 